\title{
プリムラ花弁上での灰色かび病菌の生育過程の観察法
}

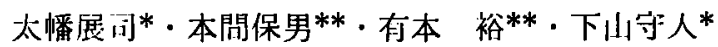 \\ Hiroshi Tabata*, Yasuo Homma**, Yutaka Arimoto** and Morito Shimoyama*: \\ An Observation Method of the Growth Stage of Botrytis cinerea on Primula Petals.
}

\begin{abstract}
For observing the growth stages of Botrytis cinerea, a simple method using petals of primula or petunia was developed. When the petals were inoculated with conidial suspension prepared from the culture of $B$. cinerea, conidial germination began by $5 \mathrm{hr}$ after inoculation. Hyphal penetration occurred by $8 \mathrm{hr}$, when conidial germination was attained to about 50\%. Conidiophores were developed within 3 to 4 days after inoculation, and sporulation was observed on the following day. The symptoms appeared by $11 \mathrm{hr}$ after inoculation, and the number of lesions reached the maximum level by $16 \mathrm{hr}$ (about 180 lesions at inoculum concentration of $10^{5}$ conidia/ml). Since the life cycle of the fungus is so quick and symptom appears so rapidly on petals, the present method is expected to be applicable for screening chemicals.
\end{abstract}

Key words : Botrytis cinerea, Primula polyantha, Petunia hybrida, growth stage, symptom occurrence.

灰色かび病は, 野荣, 果樹, 花き類などに発生する 多犯性病害で, また, 薬剂耐性菌の出現によりその防 除が困難となっている病害の一つである。この灰色か び病菌を钼察する手段として、スライドグラスが用い られてきたが，胞子発芽ならびに菌系伸長しか観察で きず1), 当然のととながら菌系侵入，発病さらに分生 胞子形成は観察不可能であった。また，手塚ら゙によ $っ て$, 発病の観察や薬剤の効果判定に輪切りキュウリ 果実を用いる方法が考案されたが, 彼等の方法では本 菌の生育過程を観察できない問題があった。そこで， 我々は, 宿主植物を用いて, 本菌の全生育過程が詳細 に観察できる方法を検討した。

この目的のために，供武忉料は随封供給できるこ と, 㵶培管理が容易であり, かつ安価に入手できるて とが必要と考えられた。こ㧈らの条件を満足する供陚 植物としてサクランゥ科の Primula polyantha Mill
（以下プリムラと記す）およびナス科のPetunia hybrida Vilm（以下ペチュニアと記す）を考えた。

発芽およひ侵入 灰色かび病菌 Botrytis cinerea Persoon を PSA 平板培地で $25 \mathrm{C}, 4$ 日間培養後, BLB ランプで 2 日間照射し，再び $25 \mathrm{C} ， 2$ 日閒培責 して分生胞子を形成させた。培地上に隇菌水 $10 \mathrm{ml}$ を 注ぎ，堿菌毛筆で分生胞子をかきとり，2 重の堿菌ガ 一ゼでろ過し，滅菌水を用いて $10^{5}$ 個 $/ \mathrm{ml}$ の胞子浱度 になるように調製した。温室内で栽培したプリムラお よびペチュニアの花部を, 開花 $2-3$ 日後に, 花梗部 から切り離し, 前述の胞子眐濁液 $5 \mu 1$ をマイクロシ リンジで花弁上に滴下して，25Cの湿室（ほほ100\%） に静置した（Plate I-1）。接種後，1 時間每汇滴下し た花弁を切り取り，100\%メタノールに 3 時問浸清し て脱色した後, コットンブルーで染色して 光顕観察 （200ー400倍）をおてなった。プリムラ花弁上では接

* 明治大学農学部 Faculty of Agriculture, Meiji University, Kawasaki, Kanagawa 241, Japan ** 理化学研究所 The Institute of Physical and Chemical Research, Wako, Saitama, 351-01, Japan

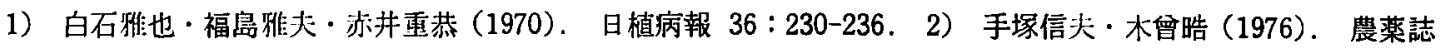
$1: 321-324$. 


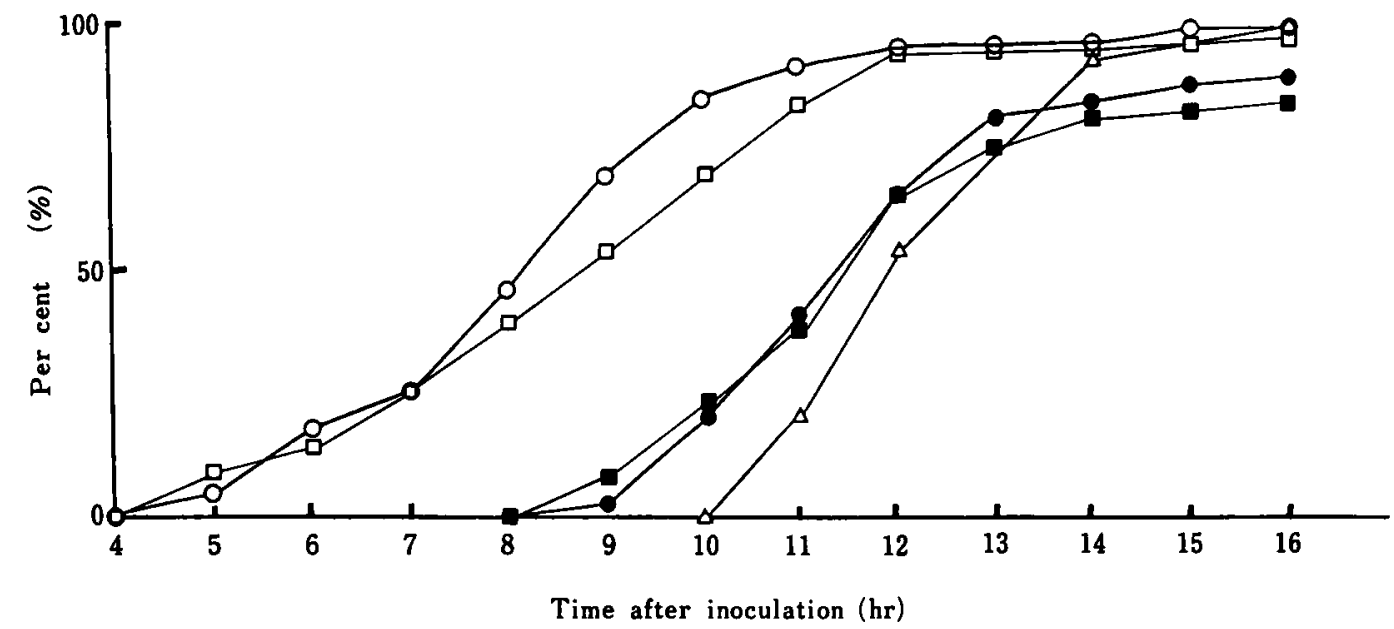

Fig. 1. The time course of each growth stage of Botrytis cinerea on the petal of Primula polyantha and Petunia hybrida.

Conidial germination on Primula polyantha.

$\square$ Conidial germination on Petunia hybrida.

- Hyphal penetration to Primula polyantha.

- Hyphal penetration to Petunia hybrida.

$\triangle$ Rate of increase of lesion number on Primula polyantha.

種後 4 時間から 5 時間目に 発芽が始まり，その発芽 率は 6 時間後には $18 \% ， 9$ 時間後には約70\% (Plate I-2)，11時間後には約90\%に達した（Fig. 1)。組織へ の侵入は約 8 時閒で始まり，12時間後には発芽胞子の 約70\%が侵入した (Fig. 1)。ペチュニア花弁上の発芽 率ならびに発芽胞子当りの侵入率を観察したところ, プリムラ花弁之同樣に，接種後約 5 時間目に発芽が始 まり，その発芽率は 8 時間後には約 $40 \% ， 11$ 時間後に は約80\%に増加した。侵入は約 8 時間後から始まり， それ以降はほぽプリムラ花弁と同じ侵入率を示した (Fig. 1)。花弁組織への侵入はすべて細胞縫合部より 行われた。

分生胞子の形成 ペチュニアおよびプリムラ化弁上 に, 上述の方法で胞子瑟濁液を点滴接種後, 1 日毎に 花弁に生じた病斑部を切り取り, 光顕により分生胞子 の形成状況を観察した。その結果, 接種後 $2 \sim 3$ 日目 には楬色病斑部表面に分生子柄が観察された。 $3 \sim 4$ 日目には, 1 分生子梗当り10 20個の卵型分生胞子が 形成された（Plate I-3)。5 日目までには，多数の分 生胞子が形成され，肉眼でもその存在が明膫に観察さ れた。プリムラ花弁上であ同様の結果が認められた。
病斑形成 供試菌による 発病の有無を検討するた め, 前述の胞子腎濁液をプリムラおよびペチュニア花 弁上に噴霧接種し， $25 \mathrm{C}$ の湿室に静置した。接種 16 時 間後, 花弁上に形成された病斑数を数え，その増加率 を時間毎に求めた（Fig. 1)。プリムラおよびペチュニ アでは, 接種11時間後まで初期病斑が形成された。 その後，侵入率の増加伴い病斑数は増加し，16時問 後には，両花弁の病斑数は最大となった (Plate I-4)。 16時間以降は隣接病斑が融合して調查が困鹤となった ので, 病斑数が最大となる接種後16時閌目を発病調查 の最適時と判断した。

以上述へたように, プリムラおよびペチュニアの花 弁は, 年間を通じ供給が可能であり, また, メタノー ルで速やかに脱色されるので，花弁上に接種された灰 色かび病菌の胞子発芽, 組織への侵入, 分生子柄およ び分生胞子形成の過程や発病が短時閒に, かつ, 詳勫 亿倠察するととが可能となった。よって，てれらの特 長から, 楽剂の効果判定に利用できるものと思われ る。

（昭和61年 3 月 14 日受理） 


\section{Explanation of plate}

Plate I

1. Petals of primula inoculated with conidial suspension ( $5 \mu \mathrm{l}$ ) of Botrytis cinerea using a microsyringe.

2. Germinated conidia of $B$. cinerea on petals of primula $9 \mathrm{hr}$ after inoculation. $(\operatorname{Bar}=20 \mu \mathrm{m})$

3. Conidial formation of $B$. cinerea on a petal of petunia 5 days after inoculation. $(\mathrm{Bar}=20 \mu \mathrm{m})$

4. Lesions on petals of primula $16 \mathrm{hr}$ after inoculation.

\section{Abbreviation}

c: conidium, $g$ : germ tube, ph: penetration hypha, $\mathrm{cp}$ : conidiophore

\section{Plate I}

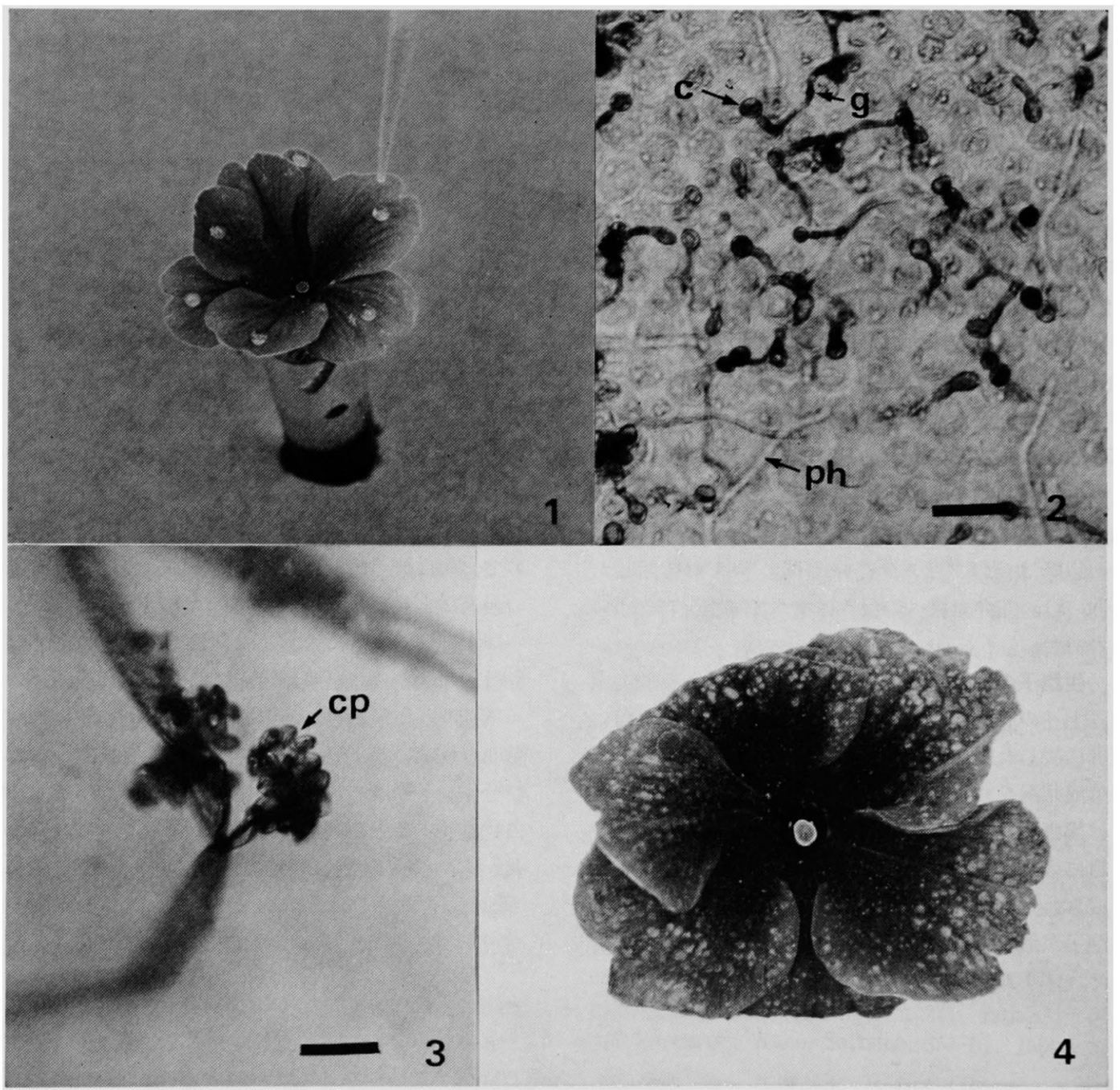

